\title{
Discounting the Political: Understanding Civic Participation as Private Practice
}

Ottilia Chareka (St. Francis Xavier University) and Alan Sears (University of New Brunswick)

\begin{abstract}
Around the world there is concern about the disengagement of citizens from participation in civic life. Emerging from that concern have been calls for new initiatives in civic education and many jurisdictions have developed and implemented new programs in the area. Much of this work has gone forward with little or no research on the prior conceptions of participation that exist among citizens. This paper reports on a study designed to map the conceptions of civic participation held by a group of recent African immigrants to Canada compared with a group of native-born Canadians. The focus here is on findings that indicate participants made a clear distinction between civic activities they saw as political and those they saw as nonpolitical. These findings coincide with theoretical literature that posits a divide between the two and raises implications for curriculum planners and teachers attempting to broaden conceptions of the political and foster engagement.
\end{abstract}

Résumé : Le désengagement des citoyens de la participation à la vie civique est un souci partout dans le monde. C'est ainsi qu'émergent de ce problème des appels au développement de nouvelles initiatives en faveur de l'éducation civique et que plusieurs juridictions ont développé et mis en œuvre de nouveaux programmes dans le domaine. Beaucoup de ce travail a été réalisé alors qu'on n'avait pour ainsi dire pas de recherche sur les conceptions de la participation qui existent déjà chez les citoyens. Cet article présente une étude qui vise à dresser le portrait des conceptions de la participation civique d'un groupe d'immigrants africains récemment arrivés au Canada et de les comparer avec celles d'un groupe de Canadiens de naissance. L'accent est mis ici sur les résultats qui montrent que les participants font une distinction claire entre les activités civiques qu'ils considèrent comme des activités politiques et celles qu'ils considèrent ne pas être politiques. Ces résultats vont dans le même sens que les théories qui posent comme postulat une séparation entre les deux et soulèvent des implications pour les planificateurs de programmes et pour les enseignants qui tentent d'élargir les conceptions du politique et d'encourager l'engagement politique.

\section{Disengagement in Civic Life and Citizenship Education}

Around the world there is growing concern about the disengagement of citizens from participation in civic life (Norris, 1999). This concern is a driving force in an explosion of interest in democratic citizenship education around the world. Over the past decade significant new policies and programs in civic education have been developed and implemented in places as diverse as England, Russia, Japan and Hong Kong, to name a few (see, for example, Banks, 2004; Lee, Grossman, Kennedy, \& Fairbrother, 2004; Sears \& Hughes, 2005). A key

50 Canadian and International Education Vol. 34 no. 1 - June 2005 
component of most of these programs is attention to developing students' commitment to civic participation.

Many current and proposed initiatives in civic education are being driven by a sense of crisis, including the perception that citizens are increasingly alienated and not disposed to participate (Sears \& Hyslop-Margison, in press). One result of educational reform as a response to crisis is a rush to implement programs without adequate knowledge of what the problems really are and what policies or programs will effectively address them. While the past several years have seen a growing body of research about the knowledge, skills and dispositions of young people with regard to citizenship (see, for example, Amadeo, TorneyPurta, Lehmann, Husfeldt, \& Nikolova, 2002; Hahn, 1998; Torney-Purta, Lehmann, Oswald, \& Schulz, 2001), knowledge in these areas is still very limited. One particular area of research where civic education lags far behind science and math, for example, is in developing a body of work about students' prior knowledge of ideas and concepts important to citizenship. Constructivists argue that good teaching is at least partly premised on attention to the conceptions/misconceptions people bring to any learning situation (Driver \& Easley, 1978; Windschitl, 2002). To be effective, civic education programs should be developed with some attention to the conceptions students already have of important civic ideas. To that end, this paper reports on a study designed to map the way a group of recent African immigrants to Canada and a group of native-born Canadians understand the idea of civic participation with particular focus on their clear division of civic participation into two categories: political and non-political.

\section{The Study}

The main purpose of the study ${ }^{1}$ was to describe conceptions of political participation among African immigrants in comparison to those held by nativeborn Canadians. Forty participants from the Maritime Provinces including twenty African immigrants and twenty native-born Canadians participated. Equal numbers of males and females as well as adults and youth were included in the study population (see Table 1).

As we were interested in uncovering students' conceptions of a particular phenomenon we employed a phenomenographic approach to the research (Marton, 1981). Phenomenography is "an empirically based approach that aims to identify the qualitatively different ways in which different people experience, conceptualize, perceive and understand various kinds of phenomena" (Marton as cited in Richardson, 1999, 53).

\footnotetext{
${ }^{1}$ The authors gratefully acknowledge funding for this research provided by the Social Sciences and Humanities Research Council of Canada, Standard Research Grant \#4102001-0083.
} 
Table 1: Participants

\begin{tabular}{|l|c|c|}
\hline Gender and Age & African immigrants & Canadians \\
\hline Female adults $(25+$ yrs $)$ & 5 & 5 \\
\hline Male adults $(25+$ yrs $)$ & 5 & 5 \\
\hline Female youth $(16-24$ yrs $)$ & 6 & 6 \\
\hline Male Youth $(16-24$ yrs $)$ & 4 & 4 \\
\hline
\end{tabular}

Phenomenographic interviews are often focused on semi-projective stimuli designed to provoke the interviewee into speaking about the concept under study (Webb, 1997). In this case, stimuli consisted of sets of pictures culled from popular media depicting various kinds of civic participation ranging from community based activities such as volunteering in a food bank through more public actions such as signing petitions or participating in demonstrations to formal political activities like voting and running for office. An effort was made to include a range of visibly diverse people in the stimuli but it proved difficult to find pictures of African-Canadians, particularly in activities related to formal politics. Rather than construct stimuli showing such involvement, we felt it was better to represent the world as it actually appeared in the media.

The interviews for this study were conducted by one of the researchers, a recent immigrant from Zimbabwe. Each one began with participants choosing one from the range of pictures and a conversation ensued exploring the reasons for selecting that particular picture or set of pictures as opposed to others. Marton (1984) argues that phenomenographic interviews should follow from participants' comments and "should not have too many questions made up in advance" (p. 27). We followed these procedures allowing each interviewee to set the direction for their interviews which were taped and transcribed.

In phenomenography, the data is treated as a whole rather than as separate transcripts and the first step in analysis is to identify utterances. An utterance is defined as a portion of a sentence that describes the phenomenon under study. Philip (1976) defines an utterance as "a verbal manifestation that conveys a meaning or evidence of understanding" (p.7). In this study, an utterance was any word or phrase within a sentence related to and reflecting an understanding of civic participation. Repeating or recurring points of view or ideas were identified in the utterances and these were clustered and classified into categories of description. These categories of description became the basis for describing the qualitatively different conceptions of political participation held by the participants. 


\section{Findings}

Eleven clearly identifiable categories of description were identified from the data. For the purposes of this paper we will focus on two: civic participation as political and civic participation as non-political.

“This is politics, are you political?" Civic Participation as Political

During the interviews, twelve photographs were used as springboards for conversation. They were grouped to portray various forms of civic participation. Most participants, when presented with each set, would make a comment classifying some of the individual photos as political and others as not political. Nearly all the people interviewed, when looking at the pictures of formal politics (voting, running for office and attending a political rally), would readily classify them as political. One participant said:

Well uh... this is political. I am not a very political person. I have never been greatly interested in politics, even small-time politics. But I guess, as you get older you realize that politics determines the direction of the country.

Another one, when looking at the same set of pictures, said, "Now we are talking politics." Someone else said, "Now we are in politics". Another said, "This is politics, are you political?" These kinds of comments were made by most of the participants from both groups, regardless of age and gender. None made any comment similar to these when looking at pictures of forms of protest or community service. In general, most people talked of formal politics as detached from them. In other words, they saw no personal connection to, or immediate tangible results from, these types of participation.

With the exception of voting, which most adults and some youth either did regularly or planned to do when eligible (both citizenship status and age were factors in eligibility), the participants largely said they did not, and probably would not participate in these kinds of formal political activities. Running for office provides a particularly good example of the responses. Nineteen out of twenty females, both recent African immigrants and native-born Canadians, explicitly, and quite vehemently in many cases, ruled out running for office. One African immigrant female youth said it had once crossed her mind to run for office; however, she would not seek election here in Canada, but would consider returning to run in her own country of origin, Botswana. Those who indicated they would not run for political office gave various reasons. Most females, both adults and youth, said they would work in the background and support those campaigning for political positions. One adult woman said, "I will never get involved, I don't think so. You know, it's fine if other people do it. I'd rather work quietly as a background researcher and provide information. I'm basically a researcher for information." While most of the men, when directly asked, saw 
running for office as a possibility for them, none expressed much spontaneous enthusiasm for it and none had done so in the past.

While virtually all participants shied away from formal participation, the reasons for this decision varied across groups. In particular Black participants, both immigrant and native-born Canadians saw race and culture as key barriers to their participation in formal politics. Several pointed out the lack of visible minorities, particularly Blacks, in the photographs and said this was an indication that Canadians would not support Black candidates for office. One participant said, for example, "You don't see any Black people in parliament today and I think maybe they're blocking or pushing Black people not to ever go in there." Colour was not the only barrier perceived here, as many Black participants talked of cultural differences between those of African and European heritage. Successful participation in formal politics, for these participants, meant adopting more 'European' cultural values and practices. In the words of one, "You should become parts of them and parts of Canada that means you should more or less become a White Black man."

"Now we are talking sense, not politics..." Civic Participation as Non-Political

In this category, most people described some forms of civic participation as nonpolitical. In contrast to the personal disconnect almost all participants felt from formal political activities, all saw themselves as personally engaged and connected to what they saw as non-political forms of participation. This emerged when participants were talking about stimuli from the pictures that reflected community service. Nearly everyone, when first shown this set of pictures, would respond in a way similar to the participant who said, "Now we are talking sense, not politics. This is me. I am excited. When I do these things, I know that I make a difference." Another participant, when shown the same pictures said, "This is all about me in these pictures. It's difficult for me to choose because I can see myself in all of them. This is my area, not politics." Someone responded by saying, "Things like this is real citizen involvement, not politics."

While none of the participants spoke of personal involvement in what they saw as political participation (beyond voting), all talked of their experience participating in community service or "non-political" activities. All of the youth, both recent African immigrants and native-born Canadians, said they were involved in volunteering activities of some type. They even expected to increase their volunteer activities.

Participants expressed a number of reasons for volunteering with some variation across groups. A key reason immigrants gave for volunteering, for example, was that they saw it as a way to meet Canadians and learn about Canadian culture. Some participants from both groups saw volunteering as a way to enhance their opportunities in life by making important personal contacts, to 
improve résumés and gain opportunities for scholarships, and the like. For immigrants, this took a more serious tone as some saw volunteering as the only way to break down barriers to employment. One who had long looked unsuccessfully for work was advised to volunteer and reported, "It worked like magic, after volunteering with the Salvation Army ... within months I got a position." Immigrant participants also reported feeling coerced into some forms of volunteering particularly fund raising in the workplace where supervisors were often responsible for organizing efforts and collecting funds.

\section{Discussion}

Theorists have long made the distinction between what they alternatively term formal and informal, conventional and non-conventional means of civic participation (see, for example, Norris, 1999; Torney-Purta et al., 2001). The former, largely regarded as public engagement, includes activities such as voting, joining political parties, or running for office. The latter, viewed as private engagement, includes fund-raising for charitable organizations and volunteering in community kitchens, food banks and other related civic activities. It is interesting that the participants in this study saw civic participation in exactly these terms.

Feminist scholars have argued that women have been largely excluded from formal political participation and have engaged, for the most part, in the private realm of community building - informal politics (Dillabough \& Arnot, 2001). Again, this study largely bears that out. It does raise questions, however, about how widely formal political activity is open to all - or even most - men. While male participants in this study did not explicitly rule out formal political activity in the way women did, they certainly did not feel comfortable with that kind of involvement and gravitated strongly to private, informal community participation. It seems the private realm is not solely the preserve of women but the venue of choice for many citizens of both genders.

While we celebrate the obvious commitment to community involvement expressed by the participants in our study, the results raise several concerns and have implications for planning curricula and programs in civic education both in schools and the community. First, we believe the results discount the political in two important and challenging ways. Government policy makers and social scientists have long been concerned about the retreat of citizens from the public realm (Torney-Purta et al., 2001). Finding some solace in what appears to be a commensurate surge in community based activities (Norris, 1999; Russell, 2002), we share Callan's (2000) concern that a withdrawal of ordinary citizens from the formal political arena is a threat to democracy. In an address to an international conference on civic education, he raised the question - if citizens do not participate in their own governance who, or what, will take their place? Rule by the people has been central to Western conceptions of democracy since 
the American Revolution; the people's discounting of the political for themselves and their retreat from the mechanisms of rule should concern us.

The second way the political is discounted in the conceptions held by our participants is in its being confined to the formal mechanisms of governance. Feminist scholars have long argued that citizenship has been too narrowly construed with inordinate focus on the public activities associated with formal politics. They have called for recognition of work in the so-called private realm of family and community development - work they argue is largely done by women - as both valuable and political. As Foster (1997) argues, recent reforms in civic education lack "a sound theoretical framework for conceptualizing women's relations with citizenship" (p. 128), leaving women and girls feeling excluded from the civic enterprise. Our participants clearly see community service as non-political and of a different order than formal political participation.

Many civic education programs focus on re-engaging citizens with the processes and institutions of representative democracy but not many, in our experience, address expanding students' conceptions of the political. While our study offers no evidence of what programs or activities will accomplish either of these, it does raise some important questions for program developers. A significant body of research demonstrates that prior knowledge is a key factor influencing learning. Ausubel (1968) points out that meaningful learning depends on organizing material in a way that connects it with the existing ideas in the learner's cognitive structures. This study indicates it will not be effective to simply explain to students the mechanisms of voting and representative government or the ways in which community involvement is political. Material and activities will have to take into account the prior knowledge learners bring with them in both an individual and collective sense, recognizing that such perceptions are persistent and will need to be engaged in meaningful ways before they will change.

\section{Conclusion}

In the literature on prior knowledge, authors use terms like alternative frameworks, misconceptions, and naive theories to refer to the conceptions students bring with them to learning situations. Recent work on young children's understandings of shelter and food, for example, portrays spotty and tacit knowledge, characterized by misconceptions and relatively low levels of sophistication (Brophy \& Alleman, 2002; Brophy, Alleman \& O'Mahony, 2003). The authors of that work argue that, “...discovering valid prior knowledge that instruction can connect with and build upon" is fundamental to effective teaching" (Brophy \& Alleman, 2002, p. 461). The point is not so much to change student's thinking as to shape, extend and contextualize it. In our 
view, sophisticated understandings of concepts and ideas include knowledge of how they have been and are understood across time and contexts.

The study reported here demonstrates that both the native-born Canadians and African immigrants who participated see value in civic participation and are engaged in substantial community based activities. This supports the work of others who have argued that rhetoric about alienation from participation in civic life may be over stated, or at least over simplified. The results also demonstrate that the participants have very limited conceptions of what constitutes "political" engagement and see their own participation as non-political and simply philanthropic. Civic education policies and programs seeking to extend conceptions of what counts as political and to develop the disposition to engage in so-called formal politics will have to begin by getting students to explicitly examine the ideas they bring with them to class, and then engage them in interpersonal dialogue with others (either directly or through readings, film etc) whose conceptions are different. In this way their ideas can be challenged, extended and seen in a broader context.

\section{References}

Amadeo, J. A., Torney-Purta, J., Lehmann, R., Husfeldt, V., \& Nikolova, R. (2002). Civic knowledge and engagement: An IEA study of upper secondary students in sixteen countries. Amsterdam: IEA.

Ausubel, D. P. (1968). Educational psychology: A cognitive view. New York: Holt, Rinehart and Winston.

Banks, J. A. (Ed.). (2004). Diversity and citizenship education. San Francisco: JosseyBass.

Brophy, J., \& Alleman, J. (2002). Primary-grade students' knowledge and thinking about the economics of meeting families' shelter needs. American Educational Research Journal, 39, 423-468.

Brophy, J., Alleman, J., \& O'Mahony, C. (2003). Primary-grade students' knowledge and thinking about food production and the origins of common foods. Theory and Research in Social Education, 31, 10-49.

Callan, E. (2000, June). Between hope and fear: The future of democratic education. Paper presented at the Building Democratic Villages, the 5th International Conference of the National Council for the Social Studies, Calgary, Alberta.

Dillabough, J. A., \& Arnot, M. (2001). Challenging democracy: International perspectives on gender, education, and citizenship. London: Taylor \& Francis.

Driver, R., \& Easley, J. (1978). Pupils and paradigms: A review of literature related to concept development in adolescent science students. Studies in Science Education, 5, 61-84.

Foster, V. (1997). Feminist theory and the construction of citizenship education. In K. J. Kennedy (Ed.), Citizenship education and the modern state (pp. 126-136). London: Falmer Press.

Hahn, C. L. (1998). Becoming political: Comparative perspectives on citizenship education. Albany, NY: State University of New York Press. 
Lee, W. O., Grossman, D. L., Kennedy, K. J., \& Fairbrother, G. P. (Eds.). (2004). Citizenship education in Asia and the Pacific: Concepts and issues (Vol. 14). Norwell, Mass.: Kluwer Academic Publishers.

Marton, F. (1981). Phenomenography: describing conceptions of the world around us. Instructional Science, 10, 177-200.

Marton, F. (1984). Phenomenography. In F. Marton, D. Hounsell \& N. Entwistle (Eds.), The experience of learning: Implications for teaching and studying in higher education (Vol. Scottish Academic Press). Edinburgh.

Norris, P. (Ed.). (1999). Critical citizens: Global support for democratic government. Oxford: Oxford University Press.

Phillip, S. D. (1976). Language development: Structure and functions. New York: Holt, Rinehart \&Winston.

Richardson, J. T. E. (1999). The concepts and methods of phenomenographic research. Review of Educational Research, 69, 53-82.

Russell, R. J. (2002). Bridging the boundaries for a more inclusive citizenship education. In Y. Hébert (Ed.), Citizenship in transformation in Canada (pp. 134-149). Toronto: University of Toronto Press.

Sears, A., \& Hughes, A. S. (2005). Learning from each other: Toward a democratic approach to international collaboration in civic education. International Journal of Citizenship and Teacher Education, 1(1), in press.

Sears, A., \& Hyslop-Margison, E. (In press). The Cult of Citizenship Education. In G. Richardson \& D. Blades (Eds.), Troubling the canon of citizenship education. New York: Peter Lang.

Torney-Purta, J., Lehmann, R., Oswald, H., \& Schulz, W. (2001). Citizenship and education in twenty eight countries: Civic knowledge and engagement at age fourteen. Amsterdam: IEA.

Webb, G. (1997). Deconstructing deep and surface: Towards a critique of phenomenography. Higher Education, 33, 195-212.

Windschitl, M. (2002). Framing constructivism in practice as the negotiation of dilemmas: An analysis of the conceptual, pedagogical, cultural, and political challenges facing teachers. Review of Educational Research, 72, 131-175.

58 Canadian and International Education Vol. 34 no. 1 - June 2005 